\title{
下顆酒の臨床的篗㲾
}

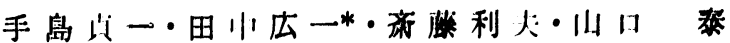

丸茂一郎*・大村武平*・藤回靖*・小松明**

河岛 正 宣***

\section{Clinical observation on carcinoma of the mandible}

\author{
Teiichi Teshima - Koichi Tanaka* - Toshio Saito - Tai Yamaguchi \\ Ichiro Marumo* - Taketoshi OHmURA* • Yasushi FujITA* • Yoshiaki Komatsu** \\ Masayoshi KaWAsHimA***
}

I. 緒

砉

UICC の悪性腫㾸分類に関する提言 ${ }^{11}$ が普及してから 日が浅く，上影痁と同しく，下影癌の名称も，日常用い られている。 それは，原発部位が歯肉か, 䫒骨中心性か 判定不能な進展例をむ包括する名称であるためにるよる のであろ5．そして，いわゆる下影癌については，従来 の研究 2 4) にもかかわらず, 臨床上の問題点が少なくな いわれわれは, 先の上額癌に関する報告5)に引き続い て，自殹例をむとに，下顥癌についての検討も試みた。

東北大学学部第 2 口腔外科学教室（主任：手 島貞一教授）

* 東北大学第学部 1 口腔外科学教室 (主任: 林 進武教授）

** 山形大学医学部附属病院歯科口腔外科（主任： 小松義明讙師）

*** 国立仙台病院料科口腔外科（主任：河島正宣医 長)

Second Department of Oral Surgery, Tohoku University School of Dentistry (Chief: Prof. Teiichi Teshima)

* The First Department of Oral Surgery, Tohoku University School of Dentistry(Chief: Prof. Susumu Hayashi)

** Department of Dentistry and Oral Surgery, University Hospital Yamagata University School of Medicine (Chief: Lect. Yoshiaki Komatsu)

*** Department of Dentistry and Oral Surgery, National Sendai Hospital (Chief: Dr. Masayoshi Kawashima)

受付日：昭和53年 7 月 6 日

\section{II. 模 察 症 例}

昭和30年 7 月より昭和42年11月までの東北大学医学 齿科口腔外科と引き続いて昭和50年10月までの東北大学 齿学部口腔外科に入院した患患者は，約20年間で，1次 症例（新鲜例）か: 169 例，2次症例（他医で既手衐の应 例）か14例であった。 それらを部位別に分類すると表1 のようになり，そのらち UICC の分類(1974) ${ }^{1)}$ に則っ た口腔癌の 1 次症例は 130 例になった。 下影の癌は4999 であり，全体の $37.7 \%$ を占め，内外の報告6)にほほ瀬似 した皟度を示している. 以下，これらの症例について， 臨床統計的に現察するとともに若干の考察を加えてみた い.

\section{III. 検索成转とその検討}

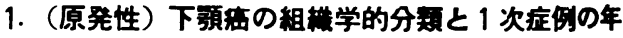 度別頻度}

原発性下預癌を組織学的に分類すれば，表 2のよ5に

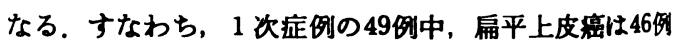
(93.9\%) を占めていた，また，2次症例 6 例中，扁平 上皮癌は 2 例であった。これに対して腺癌（粘表皮䓯，

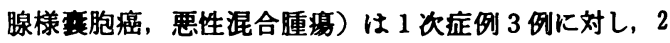
次症例は 4 例であった。

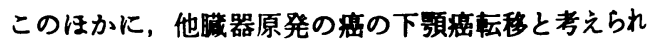
るむのが 3 例あったか，これについては別に報告する.

上記の 1 次症例について，年度别頻度をみると，医学 部歯科時代は，毎年当たりの症例数は 0 ないし 4 名, 平 均 1.1 例であったか，歯学部が発足した昭和42年以降は 1 ないし 6 例で年平均 3.6 例に增加している.

ところで，扁平上皮癌と，腺癌では，病態す異なり， 両者は臨床的に治㞠と予後の面であ区別して考える必要 
表 1 口腔領城の䖾入宽者数

\begin{tabular}{|c|c|c|c|}
\hline & 位 & 1 次症冽 & 2 次症例 \\
\hline 硬 & 蓋 & 3例 & 2例 \\
\hline 上額 & および因槽部 & 17 & \\
\hline 下額 & および困槽部 & 49 & 6 \\
\hline 煩 & 膜 & 12 & 1 \\
\hline 舌 & & 29 & 2 \\
\hline 口 & 部 & 20 & 3 \\
\hline 口映 & & (130) & (14) \\
\hline 額 & 腺 & 4 & 0 \\
\hline 上 & 洞 & 33 & 0 \\
\hline
\end{tabular}

東北大学口腔外科（昭和 30 年 7 月上り 昭和50年10月まて)

表 2 原発性下穎瘦の組䢂学的分類

\begin{tabular}{c|c|c|c}
\hline 分 類 & 1 次症例 & 2 次应例 & 計 \\
\hline 扁平上皮后 & 46 & 2 & 48 \\
粘 表 皮癌 & 3 & 1 & 4 \\
腺様の5 胞店 & 0 & 2 & 2 \\
悪性混合腫瘍 & 0 & 1 & 1 \\
\hline 計 & 49 & 6 & 55 \\
\hline
\end{tabular}

のあることは先に述べたいが，本稿ですその線に沿って 検討したい

\section{2. 下頻扁平上皮盘の検討}

1) 1 次症例 47 例の分析

(1) 年龄別，性別頻度について

表 3 のごとく，男性31例（64.7\%）に対して，女性は 15例 (32.6\%) で，男性が約 2 倍を占めていた。 好発年 龄別には，30歳代から80歳代に及んでいたか，特に50歳 ないし60歳代の症例が多く，30例であり，全体の65.2\% を占めていた.

(2) 腫瘍の好発部位について

好発部位を示すと表 4 のようになる。すなわち，下額 扁平上皮癌の腫湯存在部位については, 46例中42例(91.3

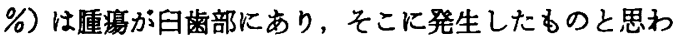
れた。 その他の 4 例(8.7\%) では，尰瘍はおすに前崡部 に存在し，遠心側はいずれる両側曰歯部まで進展してい た.この事実からみて，下簤扁平上皮癌は，はとんど日 歯部に発生し，前歯部に発生するるのは少ないるのと考 えられる.

(3) 齿牙との関連性について

腫痻が存在していた部位の歯牙の状態によって症例を 分類すると，腫燩が有齿顎部に存在していたるの 31 例 (67.4\%) と，無歯額部に存在していたもの15例（32.6

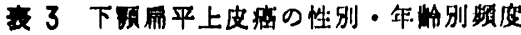

\begin{tabular}{|c|c|c|c|}
\hline & 妿 & 女 & \\
\hline 20 践 代 & 0 例 & 0 & 侧 \\
\hline 30 & 3 & 0 & \\
\hline 40 & 2 & 7 & \\
\hline 50 & 8 & 5 & \\
\hline 60 & 10 & 3 & \\
\hline 70 & 6 & 0 & \\
\hline 80 & 2 & 0 & \\
\hline 㣌 & 31 例 & 15 & 侧 \\
\hline
\end{tabular}

衰 4 下䅡扁平上皮癌の存在部位別分類

\begin{tabular}{|c|c|c|c|c|c|c|}
\hline \multicolumn{2}{|c|}{ 部 } & \multicolumn{3}{|c|}{ 位 } & \multirow[b]{2}{*}{28} & \multirow[b]{2}{*}{ 例 } \\
\hline 左 & 㑡 & 臼 & & 部 & & \\
\hline & 側 & 日 & & 部 & 14 & \\
\hline & 米 & 部 & & & 4 & \\
\hline \multicolumn{4}{|c|}{ 竍 } & & 46 & 例 \\
\hline
\end{tabular}

表 5 下額扁平上皮瘦症例の主訴（1 例 1 種目）

\begin{tabular}{|c|c|c|c|}
\hline & 有 整 & 例 & 無茵額例 \\
\hline 宷 & 痛 あり & 16 & 峩药褯創 12 \\
\hline 畨 & 痡な し & & 漬 瘏 2 \\
\hline & 尰腿・惯瘍 & 11 & 腫 脹 \\
\hline & 歯牙動据感 & 1 & \\
\hline & 迷牙淨上感 & 1 & \\
\hline & 開口障害 & 1 & \\
\hline & 践な し & 1 & \\
\hline
\end{tabular}

\%)になった，後者は全䫑無歯顥例12例と，腫核存在部 位のみの部分的無歯領例 3 例に分けられた。なお，全無

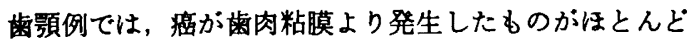
と考えられるが，そのらちの 1 例では，尰痬下に $\sqrt{8}$ が 埋伏しており，癌は表面の粘膜からか，または，埋伏雬 周用から発生したのか判定できなかった。

上記の症例について，患者の主訴のうち，おもなもの 1つずつを選んだのが表 5 である，すなわち，有歯顥例 31例では，歯痛ないし疼痛を訴えていたもの16例，腫㾤 ないし潰瘍のみで，疼痛を訴えなかったもの11例，その 他, 崡牙の動搯感, 浮上感, 開口障害のみで疼痛のない あの各 1 例であった.

これに対して，無歯䝷15例では，いわゆる義歯ずれを 主訴としていたものが12例であった，残りの 3 例ではも ともと義歯を所持せず，装着していなかったものである か，粘膜の異常に気付いて来院したものである。なお刺 


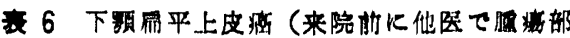
の报をうけた症例)

\begin{tabular}{|c|c|c|c|c|}
\hline 拔 茷 & 本 数 & 施: & 例 & 数 \\
\hline & 1 朴 & \multicolumn{3}{|c|}{ 5例 } \\
\hline & 2 & \multicolumn{3}{|c|}{8} \\
\hline & 3 & \multicolumn{3}{|c|}{2} \\
\hline & 4 & \multicolumn{3}{|c|}{2} \\
\hline & 11 & \multicolumn{3}{|c|}{1} \\
\hline & it & \multicolumn{3}{|c|}{ 18例 } \\
\hline
\end{tabular}

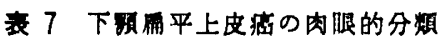

\begin{tabular}{|c|c|c|}
\hline 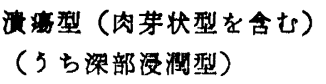 & $\begin{array}{r}42 \\
(4\end{array}$ & $\begin{array}{l}\text { 侧 } \\
\text { 例) }\end{array}$ \\
\hline 光 䫒 型 & 1 & \\
\hline 状状瘦型 & 1 & \\
\hline 白 板 型 & 2 & \\
\hline 計 & 46 & 例 \\
\hline
\end{tabular}

激となる橋義四を做去したるのは 2 例あった。

口腔癌と補綴物との関連性については，従来も寻及さ れている2゙.しかし，われわれの症例では，義崡による 機械的刺激が癌発生の要因かどらか判定は不可能であ る.

下影病の場合，患者の大多数が，雪牙の動括や齿痛を

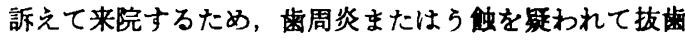
されることが多い，表 6 は，抜图された本数別に症例数 をまとめたものであるが，多数雪抜去をらけた症例は， いずれす癌が下䫑骨内を広範に浸潤しているのにすかか わらず，歯肉の表面にはほとんど露出していないるので あった。一般に，これらの患者が，最初に受診する時期

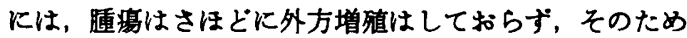
あやまって抜㦱を5けるむのと思われるが，抜崡を契機 にして腫瘍が增殖してくることから，むしろ確診がき 易くなるともいえる。すちろん抜崡せずに診断するのは 望ましいか，たとえ抜雨しても，抜雪㸗の状態を注意深 く觀察し，隀湯增殖を見逃さないことこそ大切であり， それによって，いち早く診断できれば，過ちを功名に伝 じるのる可能と考える.

上記の 46例中，尰場が大日歯部より後方に及び，開口 障害のみられたものは13例28.3\%であり，その他の33例 71.7\%では開口障害は認められなかった，開口障害の原 因は，畽瘄が目後部から内側翼突筋または咬筋に主とし て浸潤したためと思われる。なおこのよらな開口障害の みられた症例の予後は，きわめて不良で，5年生存例は 13例中わずか 2 例にすぎなかった.

(4) 肉眼的形態分類

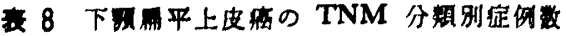

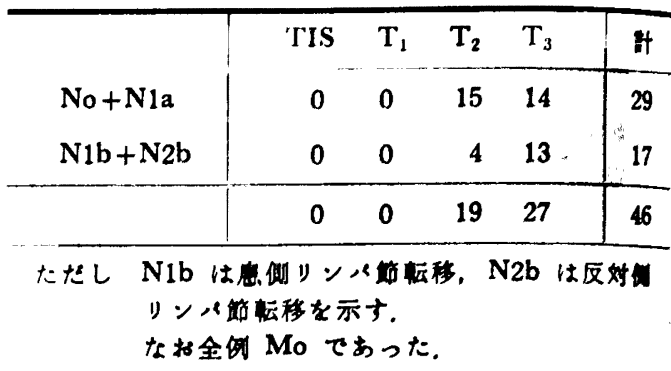

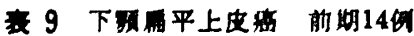

\begin{tabular}{c|c|c|c}
\hline & $T_{2}$ & $T_{2}$ & \multicolumn{1}{c}{ t } \\
\hline No & 0 & 2 & 2 \\
N1a & 4 & 7 & 11 \\
N1b & 0 & 1 & 1 \\
\hline 计 & 4 & 10 & 14 \\
\hline
\end{tabular}

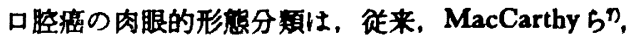

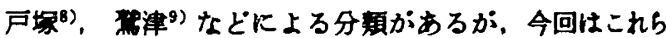
を参考に表 7 上らな分類を試みた。すなわち、下影扁

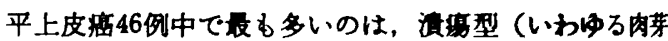
状のむのは含む) で，42例であり，91.3\%を占めてい

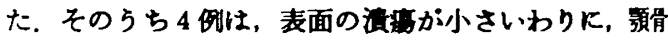

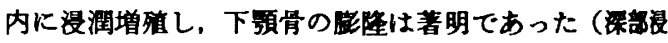
洞型）この上5なるのは，いずれる湩湯が非常に大き

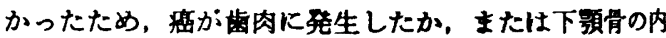
部に発生したか判定できなかったが，症例によっていい ずれの可能性もあるるのと思われた。なおその他に，日

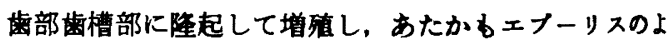
5な形態を示した乳頭型の 1 例，白色で顆粒状，全体と して低い丘状の增殖を示した获状艋型の 1 例, 白色平坦

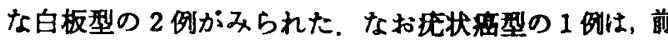
崡部舌側齿肉に発生していたか，別に舌にる多発し，遏 去に白板症として他院で数回の手街をらけていたるので ある。.な打深部浸洞型 4 例の予後は全く不良で、いす゚れ も 1 ないし 2 年で死亡していろ，また㾁状禹型，乳頭 型，白板型の各 1 例は，いずれるリンバ節枟移のために 死亡している.

\section{(5) X線学的所見の分類}

下顆扁平上皮癌46例のX線写真（オルソハンントグラ フィー，下額骨体撮影ならびに齿科用フィルムによる振

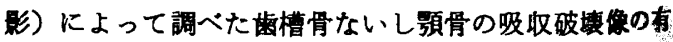
無では，全く骨の吸収を認めないのは，わずか 4 例(8.7 \%)にすぎず，42例（91.3\%）に大なり小なり骨の破搷 吸収像を認めた。

次にX線写真上の頧骨吸収の形態から, Swearingen 
表 10 下影扁平上皮满媵期 32 例

\begin{tabular}{l|r|r|r}
\hline \multicolumn{1}{|c|}{} & $\mathrm{T}_{2}$ & $\mathrm{~T}_{3}$ & \multicolumn{1}{|c}{ 计 } \\
\hline No & 7 & 1 & 8 \\
$\mathrm{~N} 1 \mathrm{a}$ & 4 & 4 & 8 \\
$\mathrm{~N} 1 \mathrm{~b}$ & 4 & 7 & 11 \\
$\mathrm{~N} 1 \mathrm{~b} \cdot 2 \mathrm{~b}^{*}$ & 0 & 5 & 5 \\
\hline 計 & 15 & 17 & 32 \\
\hline
\end{tabular}

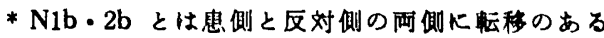
あのを示す。

ら ${ }^{10)}$ に従って分類すると, erosive type 15例 (35.7\%) と invasive type 27例 (64.3\%) に分類できた。なおX線

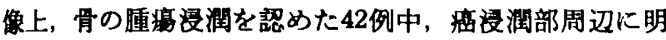
らかな骨硬化像を恋め得たものは 6 例 (14.3\%) であっ た．この点に関しては，別に報告する予定であるので省 略する。

(6) TNM 分類と進展度

UICC (1974) の TNM 分類 ${ }^{1)}$ に従って上記症例の 分類を試みたところ，表8のようになった。すなわち， TIS および $T_{1}$ は 1 例むなく，すべてそれ以上の進行 例で, $\mathrm{T}_{2}$ 19例 (41.3\%)， $\mathrm{T}_{3}$ 27例 (58.7\%) であり， また初猃時、リンハ節転移のなかったものは29例（63.0 \%)で，17例（37.0\%）に転移が認められた。 したがっ て，また $\mathrm{T}_{2}$ 症例におけるリンパ節転移率は $\frac{4}{19}=21.1 \%$ であり， $\mathrm{T}_{3}$ 症例におけるそれは $\frac{13}{27}=48.1 \%$ で， $\mathrm{T}_{3}$ 症 例のはらが転移率は高かった。 なお全例 Moであった。

ところで，これらの症例を昭和 32 年から昭和 41 年まで の前期の14例之, 昭和42年以降の後期の32例に分ける

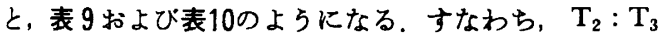

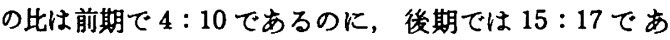
り, 後期に $\mathrm{T}_{2}$ 例が増加しているが, 他面, リンバ節転 移に関しては No+Nla : N1b+N1b・2bの比は,前期が $13: 1$ であのに対して，後期は16:16であり，むしろ 後期にリンパ節転移のある進展例が多かったことになる （なお N1b は患側，N2bは反対側，N1b・2b は両側転 移を示す).

以上の症例を進展度 Stage 別に分類すると, 表11の ようになり，I：III：IV の比は前期では 4:10:0であ るのに対して, 後期では $11: 15: 6$ となり, 後期に第 $\mathrm{V}$ 度が增加している，これは第 $\mathrm{V}$ 度は，前期では直接放射 線科に稆介し，当科には入院しなかったためと理解して いろ.

\section{(7) 治㞠法の変遷}

下顎扁平上皮癌の治療法は，手術，放射線照射，抗癌 剤の 3 者の組み合わせによって変僄しているが，これを 順を追って記すと以下のようになる。
A. 放射線照射㞠法

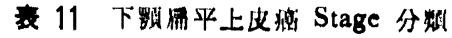

\begin{tabular}{|c|c|c|c|}
\hline & 脂倾 & 後比 & 旪 \\
\hline I & 0 & 0 & 0 \\
\hline II & 4 & 11 & 15 \\
\hline III & 10 & 15 & 25 \\
\hline \multirow[t]{2}{*}{ IV } & 0 & 6 & 6 \\
\hline & 14 & 32 & 46 \\
\hline
\end{tabular}

\section{1) ${ }^{60} \mathrm{Co}$ 針}

医学部齿科口腔外科時代に，吸和32年上り昭和33年に わたって伐用している，照射量は1 回刺入によって 240 mc ないし $480 \mathrm{mc}$ を与え，場合によっては 2 回以上繰 り返した，計 5 例に施行しているが，昭和34年以降は， 放射線治療はすへて医学部放射線科に依頼して行らよう になり，本法は施行されなくなった。

口) Tele ${ }^{60} \mathrm{Co}$ 照射

昭和34年から昭和 42 年まで主として使用し，その後む ときに施行している．照射法は主として 1 回線 $200 \mathrm{rad}$ で直交または対交 2 門，週 5 回であり，総量 6,000 rad を目標にしていたか，症例によって術前照射では 4,000 rad に止めたものもある。

八) Linac 照射

昭和43年以降，おもに使用している照射法は，分割照

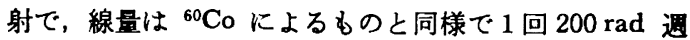
5 回法である。総線量は4,000ないし6,000 rad で症例に より加減した。

\section{B. 癌化学療法}

1) Bleomycin

当科では，昭和44年から本剂を使用しはじめた，最初 は 1 回30 mg 静注で週 2 回とし, 計10回を1クールとし て施行したが，症例によって加減した。なおのち 1 回使 用量は $15 \mathrm{mg}$ になった。 また浅側頭動脈内㨉管による外 项動脈内持続動注法を導入してから，ときに本剂を使用 し，1日量は䄪 $5 \mathrm{mg}$ を注入した。

) $5 \mathrm{FU}$

外頸動脈内持続動注法には，本削を積極的に用いた か，主として上䫑癌が多く $(29 \text { 例 })^{5)}$, 下頼癌は 6 例のみ であった. シャーブ社製の DIP-21型ポンプによって 1 日 $250 \mathrm{mg}$ を注入するのを原則にし, 同時にノポへハリ ン $0.5 \mathrm{ml}$ を混注した。

上記の薬剂のほか, 以前に Endoxanなども用いた が，例数少なく省略する。

C. 放射線療法之癌化学療法の併用

Linac X線または電子線照射に Bleomycin (静注),

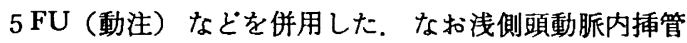
の不可能な場合には FT207 の経口投与を併用した。

表12は以上のような合併療法と手術療法との組み合わ 


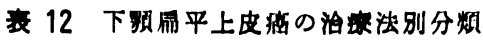

\begin{tabular}{|c|c|c|c|c|}
\hline \multicolumn{2}{|c|}{ 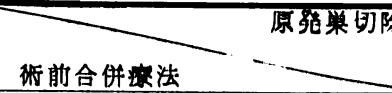 } & \multirow[t]{2}{*}{ 非切除 } & 切除 & 䎣 \\
\hline な & L & & $6(2)$ & $6(2)$ \\
\hline 放 & $\begin{array}{l}{ }^{60} \mathrm{Co} \text { 猃 } \\
\text { Tele }{ }^{60} \mathrm{Co} \\
\text { Linac }\end{array}$ & $\begin{array}{l}2(0) \\
0 \\
2(0)\end{array}$ & $\begin{array}{l}3(0) \\
9(2) \\
5(2)\end{array}$ & $\begin{array}{l}5(0) \\
9(2) \\
7(2)\end{array}$ \\
\hline $\begin{array}{l}\text { 化 } \\
\text { 学法 }\end{array}$ & BLM 㭌注 & $1(0)$ & $1(0)$ & $2(0)$ \\
\hline $\begin{array}{l}\text { 放 化 } \\
\text { 期十学 } \\
\text { 線 } \\
\text { 法 }\end{array}$ & $\begin{array}{l}\text { Linac + BLM } \\
\text { Linac +5FU 蛙注 } \\
\text { Linac+FT } 207\end{array}$ & $\begin{array}{l}2 \\
5(1) \\
2(1)\end{array}$ & $\begin{array}{l}5(3) \\
1(0) \\
2(1)\end{array}$ & $\begin{array}{l}7(3) \\
6(1) \\
4(2)\end{array}$ \\
\hline \multicolumn{2}{|r|}{ 部 } & $14(2) 3$ & $32(10)$ & $46(12)$ \\
\hline
\end{tabular}

表 13 Stage 别分類と手䛧

\begin{tabular}{c|cc|c}
\hline & 非切除 & 切 除 & 計 \\
\hline II & 2 & 13 & 15 \\
III & 6 & 19 & 25 \\
IV & 6 & 0 & 6 \\
\hline 計 & 14 & 32 & 46 \\
\hline
\end{tabular}

せを表にしたすのであって，綎楖に術前処圈（ほほ年代 順に配列）をとり，横楖に手術の有無をとったものであ る.これによれば非切除例は14例，切除例は32例となっ た. なお非切除例とは原発巣の切除を施行しなかったも のを指し，転移リンパ節だけの摘出を施行したるのを含 んでいる.

表13は癌進展度 Stage 別に非切除例之切除例を分類 したあのである．万ち，第 $\mathbb{V}$ 度の 6 例はすべて非切除例

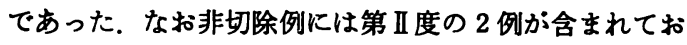
り, 放射線照射と癌化学療法の併用を施行している。 そ こで, 症例を前期（昭和32年から昭和41年）と後期（昭 和 42 年より昭和 50 年) に分けると，切除率（全例に対す

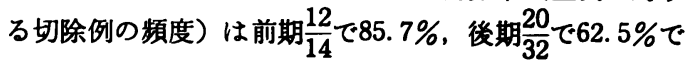
あり，全期間を通して $\frac{32}{46} て ゙ 69.6 \%$ とった。このよう に, むしろ後期の切除率が低くなったのは, 前述のよ5 に前期では進行例がおおむね放射線科に入院して除かれ ているためああると思われる。

次に手術術式の種類について分類すると表14のように なった. なお H は Hemimandibulectomy（半側下顎離 断), Cは Continuous resection (連続離断)， P は Partial resection（部分切除）を示しており，Rはリン 八節廊清を示す.すなわち $R_{0}$ はリンバ節廊清を施行し なかった例， $\mathrm{R}_{1}$ は level 1 のリンハ節のみ廊清した例,

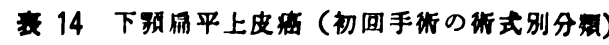

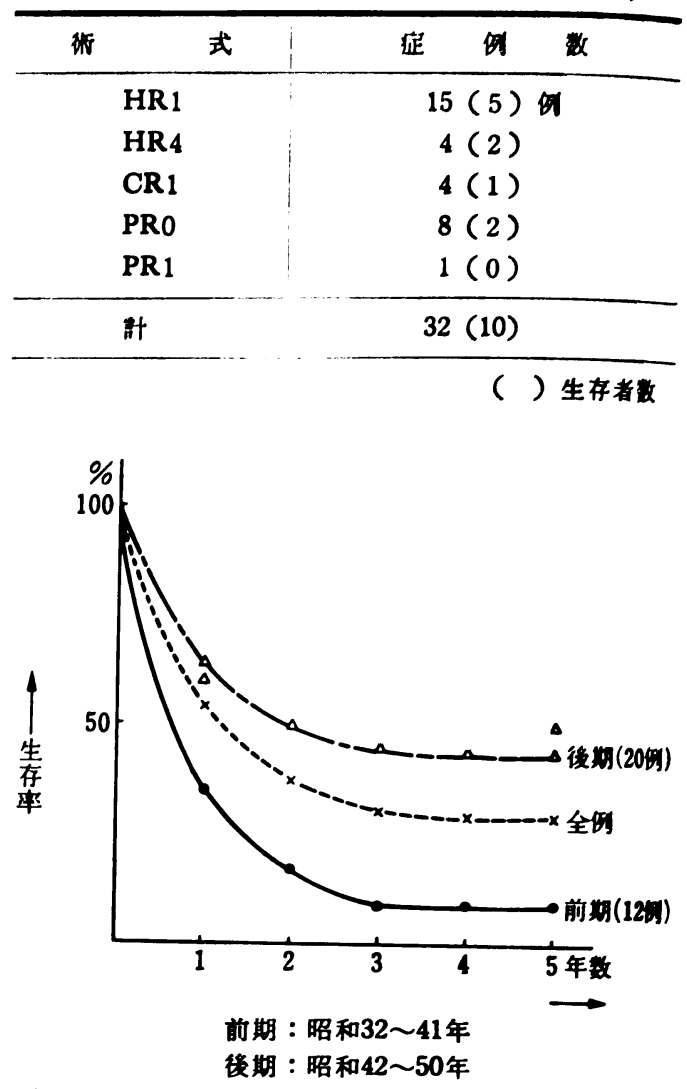

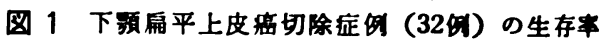

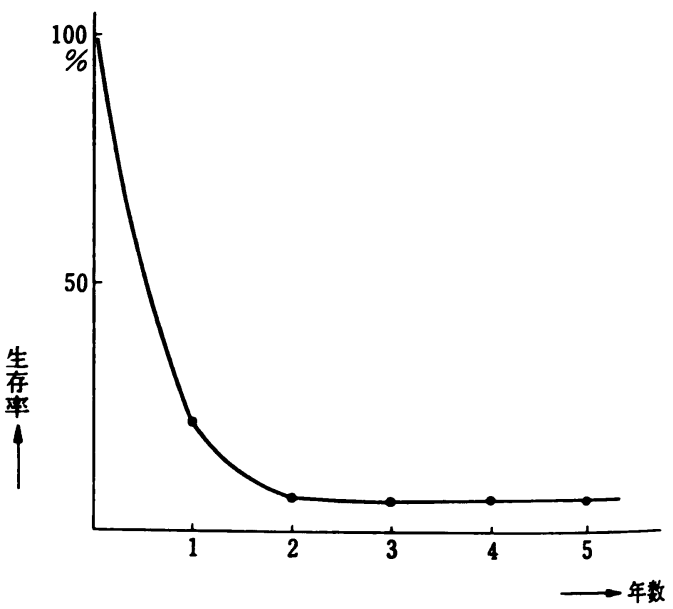

图 2 下額扁平上皮蝮非切除症例(14例)の生存事

( $\mathbf{R}_{\mathbf{2}}$ および $\mathbf{R}_{\mathbf{3}}$ あ同様であるが症例なし)， $\mathbf{R}_{4}$ は level 1, 2,3,4 のリンパ節の廕清を施行した例である。（） 内にはそれぞれの生存者数を示した。 
表 15 下額扁平上皮癌症例の死因

\begin{tabular}{|c|c|c|}
\hline 死 因 & 切 除 例 & 非切除例 \\
\hline 畽 瘏 死 & 18 & 9 \\
\hline 術後合併症 & 3 & 2 \\
\hline 他 病 死 & 1 & 1 \\
\hline 計 & 22 & 12 \\
\hline
\end{tabular}

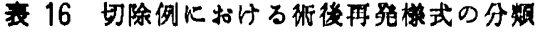

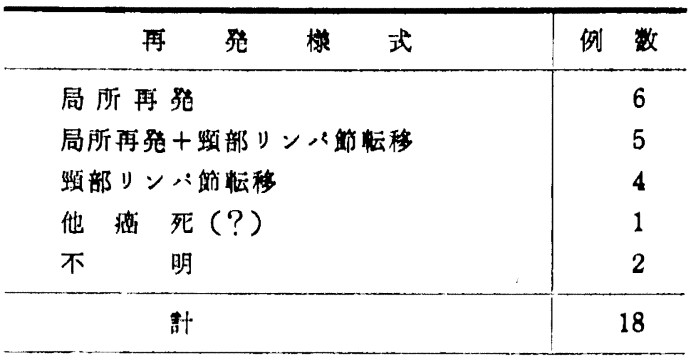

表 17 非切除にした原因

\begin{tabular}{|c|c|c|c|c|}
\hline 年 龄 & TNM & Stage & 合 併 症 & 于 後 \\
\hline \multicolumn{5}{|c|}{ [高度進展＋poor risk] } \\
\hline 70 & $\mathrm{~T}_{3} \mathrm{~N} 1 \mathrm{aMo}$ & $\mathbb{I I}$ & 心筋障㸃 & $\mathrm{L}_{5}$ \\
\hline 61 & $\mathrm{~T}_{3} \mathrm{~N} 1 \mathrm{~b} 2 \mathrm{bMo}$ & IV & 心房勫動 & $\mathrm{D}_{1}$ \\
\hline 65 & $\mathrm{~T}_{3} \mathrm{~N} 1 \mathrm{~b} 2 \mathrm{bMo}$ & IV & 脸軟化 & $\mathrm{D}_{1}$ \\
\hline 73 & $\mathrm{~T}_{3} \mathrm{~N} 1 \mathrm{aMo}$ & $\mathbb{I I}$ & 貧 血 & $\mathrm{D}_{1}$ \\
\hline 83 & $\mathrm{~T}_{3 \mathrm{~B}} \mathrm{~N} 1 \mathrm{bMo}$ & $\mathbb{I I}$ & 貧 血 & $D_{1}$ \\
\hline 57 & $\mathrm{~T}_{3 \mathrm{~B}} \mathrm{~N} 1 \mathrm{~b} 2 \mathrm{bMo}$ & IV & 畈硬变，食道静脈濾 & $\mathrm{D}_{1}$ \\
\hline \multicolumn{5}{|l|}{ [高度進展] } \\
\hline 58 & $\mathrm{~T}_{3 \mathrm{~B}} \mathrm{~N} 1 \mathrm{a} 2 \mathrm{bMo}$ & IV & & $D_{1}$ \\
\hline 50 & $\mathrm{~T}_{3 \mathrm{~B}} \mathrm{~N} 1 \mathrm{~b} 2 \mathrm{bMo}$ & $\mathbb{N}$ & & $\mathrm{D}_{2}$ \\
\hline 62 & $\mathrm{~T}_{3 \mathrm{~B}} \mathrm{~N} 1 \mathrm{~b} 2 \mathrm{bMo}$ & N & & $\mathrm{D}_{1}$ \\
\hline \multicolumn{5}{|l|}{ [poor risk] } \\
\hline 60 & $\mathrm{~T}_{2} \mathrm{~N} 1 \mathrm{bMo}$ & II & 結尿病・結核 & $\mathrm{D}_{1}$ \\
\hline \multicolumn{5}{|l|}{ [治䈍期待] } \\
\hline 50 & $\mathrm{~T}_{3}$ N1aMo & $\mathbb{I I}$ & & $\mathrm{D}_{1}$ \\
\hline 65 & $\mathrm{~T}_{3}$ N1aMo & $\mathbb{I I}$ & & $D_{1}$ \\
\hline 77 & $\mathrm{~T}_{2} \mathrm{NoMo}$ & II & & $\mathrm{D}_{1}$ \\
\hline 79 & $\mathrm{~T}_{2} \mathrm{NoMo}$ & II & & $\mathrm{L}_{2}$ \\
\hline
\end{tabular}

表 18 後期症例の進展度（很式と予後の関係）

\begin{tabular}{c|c|c|c}
\hline 進展度 & II & II & 計 \\
\hline PR0 & $2 / 6$ & & $2 / 6$ \\
PR1 & & $0 / 1$ & $0 / 1$ \\
CR1 & & $0 / 1$ & $0 / 1$ \\
HR1 & $2 / 2$ & $3 / 6$ & $5 / 8$ \\
HR4 & $1 / 1$ & $1 / 3$ & $2 / 4$ \\
\hline 計 & $5 / 9$ & $4 / 11$ & $9 / 20$ \\
\hline
\end{tabular}

生存例/全例数

\section{８）予後（遠隔成續）}

46症例の予後を非切除例14例之切除例32例に分けて検 討した. 非切除例14例中生存者は 2 例のみであり（1 例 は 5 年生存, 1 例は 2 年生存), また切除例では 32 例中
10例生存である。これらについてそれぞれ絶体生存率曲 線を画いたのが图1および図2である。すなわち下影扁 平上皮癌のらち，切除例の 5 年生存率は $29.2 \%$ であった が，これを前期（昭和32年より昭和 41 年まで）の12例に ついてみれば $8.3 \%$ と不良であったが，後期（昭和 42 年 より昭和50年まで）の20例については $50.0 \%$ と成績は向 上している. なお非切除例の 5 年生存率は $8.3 \%$ であっ た。

表15は，切除例中死亡した22例と，非切除例中死亡12 例の死因を列記したものである，切除例では，腫瘍死 （再発）かi18例で他病死 1 例, 前期の最初のころの術後 合併症による死亡 3 例となっている。 また非切除例で は, 腫瘍死は 9 例で, 食道静脈瘤破裂による

例, 癌化学療法剤の副作用に上る死亡 2 例 (Bleomycin による急性間質性肺炎 1 例と $5 \mathrm{FU}$, BudR に上る急性 下廊症によるショック 1 例）となっている。 
次に切除例中，再発死亡したものの死区を，周所再発 とリンバ節伝移に分けて示すと表16のよらになった，局

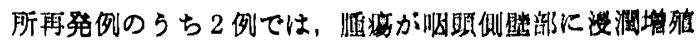

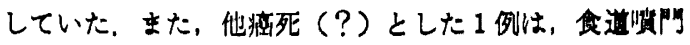

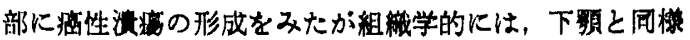

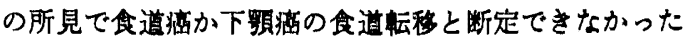
ものである.

\section{(9) 治措法と予後との闻}

立す非切除例について非切除とした理由をあげると表 17のよらになる。多いのは，遁影が高度に進展して いる上に，一般状照が不良で poor risk と判定されたる の 6 例であり，次いで一般状的は良いか，高度進展のた

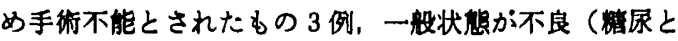
結核のため)として Bleomycin と照射を併用した 1 例， 前期に ${ }^{60} \mathrm{Co}$ 針に上る組織内照射を試みた $\mathrm{T}_{8} \mathrm{~N} 1 \mathrm{a}$ の 2 例，高秢のため Bleomycin 觧注施行した 1 例および照 射と FT-207経口投与を併用した 1 例 (いずれる $\mathrm{T}_{2} \mathrm{No}$ Mo）などの計14例であった。表12の非切除の項にみる ごとく，生存は 2 例で，その 1 例は70筬 $\mathrm{T}_{3} \mathrm{~N} 1 \mathrm{aMo}(\mathbb{I})$

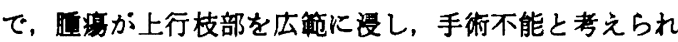
たか， $5 \mathrm{FU}$ 動注 3,250 mg と Linac 8,100 rad 照射併 用により 5 年生存して括り，また他は79歳 $\mathrm{T}_{2}$ No で FT $20720.4 \mathrm{~g}$ と ${ }^{60} \mathrm{Co}$ 照射 6,000 rad Kよって 2 年生存中 である。

現時点で手術適応の可否について反省すれば $\mathrm{T}_{8} \mathrm{~N} 1 \mathrm{~b}$. $2 \mathrm{bMo}(\mathbb{N})$ の症例についてはおのずから限度を認めねば ならないが II 度および吕度の症例については，麻醉技術 の進歩とあいまって，適応の拻大を図るべきものと考え ている.

次いで切除例について，術式別に予後を検討してみた い. 成績の悪かった前期の症例を除いて後期の切除例20 例について, 進展度, 治療法, 予後を示すと表18のよ5 になる。.すなわち PRo 施行例 6 例の進展度はすべて第 II度であるか，5ち4 例は再発死している。.また残りの 第 II 度症例は，HR $\mathrm{HR}_{1}$ 施行例は 2 例中 2 例生存, $\mathrm{HR}_{4}$ 施. 行例は 1 例中 1 例生存しているのをみれば，第 II 度症例 といえどす小範囲の保存的手術では再発の危険性が高い ことを示している。

第度症例に対して PRoを施行したものはない. $\mathrm{PR}_{1}$ を施行したものは 1 例, $\mathrm{CR}_{1}$ も 1 例でいずれる死 亡している， $\mathrm{HR}_{1}$ 施行例では 6 例中 3 例生存, $\mathrm{HR}_{4}$ で は 3 例中 1 例生存である。つまり第吕度の症例では, 肉 眼的には下額骨部分切除で根治可能と思われても実際は 尰場残存の危険が大きいことを示している。 また $\mathrm{HR}_{1}$

（下顎骨半側離断および顎下部遊清術）施行例中死亡 3 例の死因をみると、リンパ節転移のみが 1 例，局所再発 およびりンパ節転移が 2 例であった。これは術後にリン バ節転移が筫下部に止まらず， level 2 に及んだことを 示し，このよらな症例には，頸部リンパ節廓清の範囲を
さらに胁大ナぺをとをを意味している。

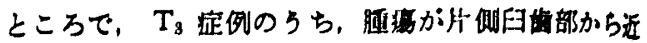

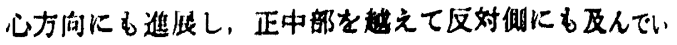
た諚例か：2例めった。 われわれは便宜上，これを $\mathrm{T}_{3 \mathrm{~B}}$ (Bilateral 西側性)としたがこれは，それぞれ HR,

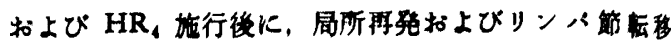
(いすれれる $\mathrm{N}_{2 b}$ ) を生して死亡している。一般に $\mathrm{T}_{3 B}$ 症例は，X線军真（特にオルソハントモクラフィー）て

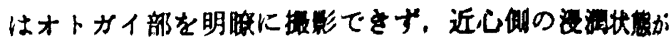
分かりにくいらえ，ともすれは切除簀围が不足となりが ちで盾为の残存をきたすためと考えられる。

$\mathrm{T}_{3 \mathrm{~B}}$ 例は，今回模狽した46例中 9 例であり，そのらち

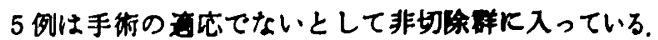

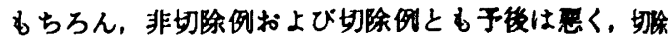
例中 2 例は 2 年死亡, その他はナへてて 1 年死亡してい 3.

なお，前达したことく，用口障害をきたした後方暹展 例については，予後は全く不良であった。

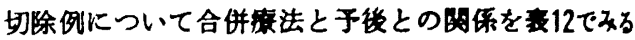
と, 非衍前照射群 6 例中 2 例生存, 術前照射群17佂中 4 例生存, 術前化学䔔法群[Bleomycin 解注] 1 例中生存坛 し, 術前照射化学撩法群 8 例中 4 例生存となっており,

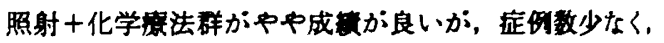
差は明らかでない。しかし，主として ${ }^{60} \mathrm{Co}$ 遠隔照射 よった前期に比して後期の成期か向上しているのは, 手 術手技の向上ととるに合併寮法の改良に上るところる大 きいすのと解釈したいところである。

ところで合併㞠法の主役をなす術前照射の协果㤌大き いと思われるが，一方，元来の尰激の界が不明にな ク，ときには顕徽鏡的な艋細胞の残存による再発をきた すなどの短所があるのは認めねばなるまい。したがって 切除範囲の決定は真重にすべきである。 また他方，缩前 照射，化学㫫法の施行中に，海がさらに進展し根治の時 期を逸することも，ときに経除することで，合併海法の 改良が望まれるととるに，現段陼ではその道灾の是非も 症例によって娭討すべきであろらと考える。

2) 下影扁平上皮密の 2 次症例について

わずか 2 例である。. 1 例は白板症を合併した小啮部 の疮状癌で数回摘出を5けていたか，当科で切除 $\left(\mathrm{PR}_{0}\right)$ して治虑した。汪かの1 例は前齿部に発生し，他院て Bleomycin と Mitomycin の併用後切除 $\left(\mathbf{P R}_{1}\right)$ L, 後 照射む5けているが，3年 5 か月後に咽頭側壁部粘填に 再発し，当科入院後，照射，化学㞠法の甲斐なく死亡し ている ( 4 年死亡).

\section{3. 腺船系下䫑寉の检討}

症例の内訳は表 2 のよ5であった，粘表皮癌の 3 例 ( 1 次症例 $)^{10,11)}$ お。び腺様の5胞癌の 1 例 ( 2 次症例)

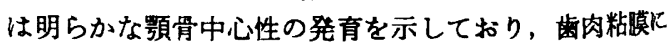
潰瘍は認められなかった。粘表皮癌の 1 例11)ではX線写 
真上， $\sqrt{8}$ の齿冠を曲んであたか子濾胞性歯の5胞のよ らな所見を示していた，また粘表皮瘦の１例は下顒骨体 に正中部を越えて浸潤性增殖を示し，X線像で胃新生像 （外骨膜性）を恋めた。

治療は，切除と術前照射，化学娃法を併用したが，放 射線照射および抗癌郕のいずれも妙果は認めがたかっ た. 1 次症例之 2 次症例を含めて 5 年生存は 7 例中 3 例 であり，はかに 3 年生存 1 例， 4 年死亡 1 例， 1 年死亡 1 例であった（不明 1 例).上部の 5 ち粘表皮痁の 1 例は， 再発を絽り返しながら，局所再発と肺および解鲜枟移の ため，13年目に死しした，本群の桩事が局所再発の多か ったことをみると，放射線感受性の低いことも勘案すれ ば，初回手術で取り残しのないよらに心掛けるのが，特 に大切であろ5．なお 7 例中 3 例に肺転移（粘表皮虞， 悪性多形性腺腫，腺様の5胞癌各 1 例）をみたことは， 扁平上皮窝と異なる特畏であると考える。

\section{IV. 考宾}

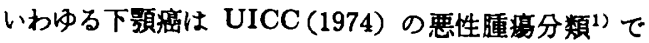
は gingiva and alveolus に分類され，わが国です报近で は，歯肉癌として報告されるすのが多くなっている゚,13). ときには上顎と下筫を一諸にした報告すある6). しかし， 上顠癌を雷肉原発と洞原発に分けるのが決して容易之は 限らないよらに, 下額の扁平上皮癌を歯肉癌と中心性瘦 に分けることも全く問題なしとはいえない，今後早期癌 が増えるにつれて組織発生面での究明が期待される.

下䫟癌の大半は扁平上皮癌であり，その病態の研究と 治療法の改良が最重要の問題であるのはいらを待たな い. 下頢癌の療法として, 従来から, 放射線治療と手術 療法の優劣が論じられていたが2,6)，いずれの方法もかな りに進歩した今日では，早期例については問題は少な く，今もなお跡を断たない進行例に対する治療法が問題 である.

近来，口腔扁平上皮癌の治療成儥は全般的に向上して いるが,特に上頻癌に関しては, 外頸動脈内注入法（動注 法)による抗癌剈と照射の併用によって, 根治的上顠全摘 術の必要性は大幅に減少するほどの改善をみているが5), 一方こと下影癌に関しては,なお工夫の余地があり, 今 回のわれわれの成䋶も諸家の成績 ${ }^{2,3,6)}$ に比較して満足で きるすのでなく,反省すべき点が多かったと感じている.

したがって，下䫇癌の場合は，組織像のいかんを問わ ず，な敃根治的切除手術の意義が薄れていないことを念 頭に置きながら，照射と抗癌剤による合併療法の改良に も努力すべきであろう。

$$
\text { V. 結語 }
$$

1）過去20年間に当科で入院治療した原発性下影癌の

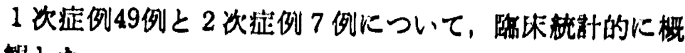
䂓した。

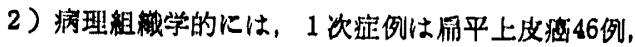
粘表皮痤 3 例であった。

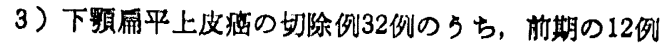
では 5 生串8.3\%はであったか，後期の20例では 5 生禹 $50.0 \%$ あり, 平均は29.2\%であった。

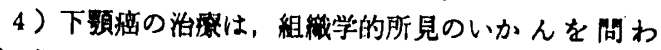
ず，根治的切除の時期を逸しない上5にすることがなお 現時点では大切であると考える。

本学医学部放射線学救空の星野文应教授, 菊地章助教

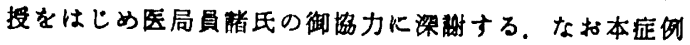
はすへて, 東北大学紫学部口腔外科勭主任・故前田柴一 教授在任中の症例であり，治楼当時の教室員睹氏に上 って施行されたるのである。

\section{引用文献}

1) UICC: TNM classification of malignant tumours. UICC. Geneva, 2nd Ed. 1974.

2）上野正，他口腔瘦の法々予後比两研究

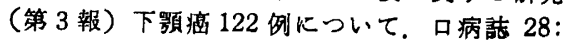
4321961.

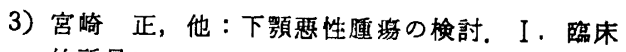
的所見について。 日外誌 19:5 1973.

II. 病理学的所見比つい。同前 19:10 1973.

4）前田栄一，他：口腔瘦の診断と治檫。 みちのく 菌学誌 6: 11975.

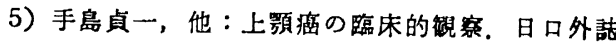
23: 5251977.

6）上野正：口腔癌，最近の研究展望。癌の臨床 20: 1691974.

7) MacCarthy, P.L., et al.: Disease of the oral mucosa, diagnosis, management, therapy. McGraw Hill, New York, 1964.

8）戸塚盛雄：口腔湎城悪性属掦新鮮症例の臨床組 織および細胞学的研究. 口病誌 38: 941971.

9）鴙津邦雄：口腔癌の現状とその動向，（上）自 験例を中心に。茵界展望 47:357 1976. 同(下) 同前, 47: 5111976 .

10) Swearingen, A.G., et al.: Roentgenologic pathologic correlation of carcinoma of the gingiva involving the mandible. Am J Roentg: 96151966.

11）服部繁雄，他：下影骨中心性粘表皮活の 2 症 例. 日外誌 17：445 1971 .

12）丸茂町子, 他: 下颖骨中心性粘表皮瘦の 1 症

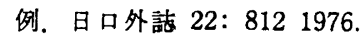

13) Wilkins, S.A., et al.: Cancer of the gingiva. Surg Gynec Obstet 105: 1451957. 